\title{
Back-scattered Electron Tomography and X-Ray Microanalysis of Zirconolite in Lunar Granite 12032,366-19
}

\author{
S.M. Seddio, * B.L. Jolliff,* R.L. Korotev,* and P.K. Carpenter* \\ * Dept. of Earth and Planetary Sciences and the McDonnell Center for the Space Sciences, 1 Brookings Dr., \\ St. Louis, MO 63130
}

Sample 12032,366-19 is a recently characterized $21.3 \mathrm{mg}$ lunar granite composed of minerals expected from late-stage fractional crystallization-K-feldspar $\left(\mathrm{KAlSi}_{3} \mathrm{O}_{8}\right)$, quartz $\left(\mathrm{SiO}_{2}\right)$, sodic plagioclase, $\mathrm{Fe}-\mathrm{Ca}-$ pyroxene, and Fe-olivine [1,2]. 12032,366-19 has been reported to contain "two Zr-Ti-Fe-rich phases" [2], which [1] previously identified as "zirkelite" [(Ca, Th, $\left.\mathrm{Ce}) \mathrm{Zr}(\mathrm{Zr}, \mathrm{Ti})_{2} \mathrm{O}_{7}\right]$. We use back-scattered electron (BSE) tomography and X-ray microanalysis to prove 12032,366-19 contains only one Zr-Ti-Fe-rich phase, which is zirconolite.

The mineral assemblage of 12032,366-19 was characterized by BSE imaging using the 5-spectrometer JEOL 8200 electron microprobe at Washington University (which includes a high-intensity LIFH/PETH H-type spectrometer). Images were generated at an accelerating voltage of $15 \mathrm{kV}$ and a beam current of $25 \mathrm{nA}$. Quantitative mineral compositions were determined by WDS EPMA using the Probe for EPMA software developed by Probe Software, Inc. Qualitative zirconolite compositions were determined by a silicon-drifted EDS. Analytical standards included synthetic and natural silicate, oxide, and REE glass standards of [3] and [4] for primary calibration, which were checked against secondary standards.

Analyses of lunar zirconolite [(Ca, REE) $\left.\mathrm{Zr}(\mathrm{Ti}, \mathrm{Nb}, \mathrm{Ta})_{2} \mathrm{O}_{7}\right]$, a common accessory mineral in evolved lunar rocks, rarely have $\mathrm{SiO}_{2}>0.3 \mathrm{wt} \%$ [3,4]; however, the observed zirconolite analyses of 12032,366-19 indicate concentrations of up to $22.2 \mathrm{wt} \% \mathrm{SiO}_{2}$. Fig. 1 shows that analyzed oxide concentrations anticorrelate with $\mathrm{SiO}_{2}$, implying that $\mathrm{SiO}_{2}$ from other minerals such as quartz and $\mathrm{K}$-feldspar is effectively 'diluting' the other oxides in the analysis. Most of the zirconolite grains are finely elongate $(\sim 3 \mu \mathrm{m}$ wide, aspect ratio of $\sim 30)$. Analyses of these grains contain $\sim 12 \mathrm{wt} \% \mathrm{SiO}_{2}$ resulting from electron beam interaction volume overlap because the grains are so thin. There is one grain of zirconolite $(100 \mu \mathrm{m}$ long and $40 \mu \mathrm{m}$ wide $)$ which is large enough that there should not be beam overlap, but the analyses of this grain have the most $\mathrm{SiO}_{2}(11.1-22.2$ $\mathrm{wt} \%$ ). We took three back-scattered images of the area at 5, 15, and $25 \mathrm{kV}$ accelerating voltages (Fig. 2). At 5 $\mathrm{kV}$, a portion of the large zirconolite grain is overlain by K-feldspar and silica. At $15 \mathrm{kV}$, the K-feldspar and quartz on top of the large zirconolite grain is mostly transparent; quartz is partially visible through the thinner portions of zirconolite. At $25 \mathrm{kV}$, all phases on top of the zirconolite are completely transparent, and roughly a third of the large zirconolite grain is partially or completely transparent.

The thickness of the phases (or portions of phases) can be constrained using Monte Carlo simulations. Using the Casino program [5], we ran simulations of 5000 electron trajectories each at 5,15 , and $25 \mathrm{kV}$ on models consisting of K-feldspar overlying zirconolite and zirconolite overlying quartz, while varying the top layer thickness. We constrained the thickness by noting if the back-scattered electrons remained only in the top phase at different accelerating voltages. Where K-feldspar overlies zirconolite, the K-feldspar is modeled to be 120 to $180 \mathrm{~nm}$ thick (Fig. 3). Where zirconolite overlies quartz, the thinnest portions of zirconolite are modeled to be 70 to $150 \mathrm{~nm}$ thick (Fig. 3). These thicknesses were confirmed by comparing EDS spectra from the sample with modeled EDS spectra generated using the NIST DTSA-II program [6] (Fig. 4).

We conclude that 12032,366-19 zirconolite contains $<0.008 \mathrm{wt} \% \mathrm{SiO}_{2}$. All zirconolite analyses with more $\mathrm{SiO}_{2}$ include neighboring (horizontally and/or vertically) phases in the analyzed volume. BSE tomography is a simple technique that can resolve whether an analysis is sampling a single phase or multiple phases.

References

[1] S.M. Seddio et al., LPSC. 40 (2009) 2285.

[2] S.M. Seddio et al., LPSC. 40 (2010) 2688. 
[3] M.J. Drake and D.F. Weill, Chemical Geology, 10 (1972) 179.

[4] P. Carpenter et al., Journal of Research of NIST, 107 (2002) 703.

[5] R.J. Needs et al, Journal of Physics: Condensed Matter, 22 (1992) 023201.

[6] N.W.M. Ritchie, Microsc. Microanal., 15 (2009) 454

[7] This work was funded by NASA grant NNG04GG10G (RLK).

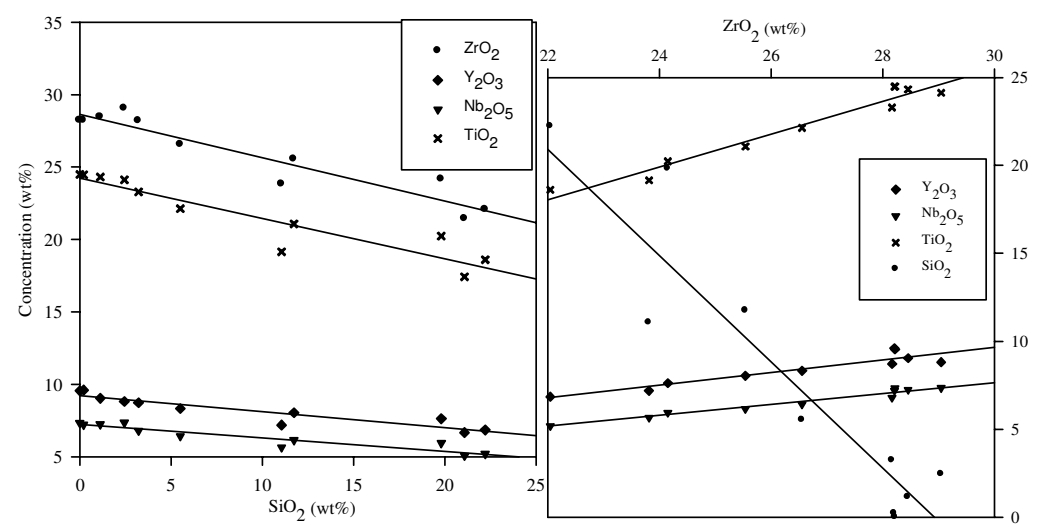

FIG. 1. In 12032,366-19 zirconolite, $\mathrm{SiO}_{2}$ is anticorrelated with other oxides, while $\mathrm{ZrO}_{2}$ is directly correlated.
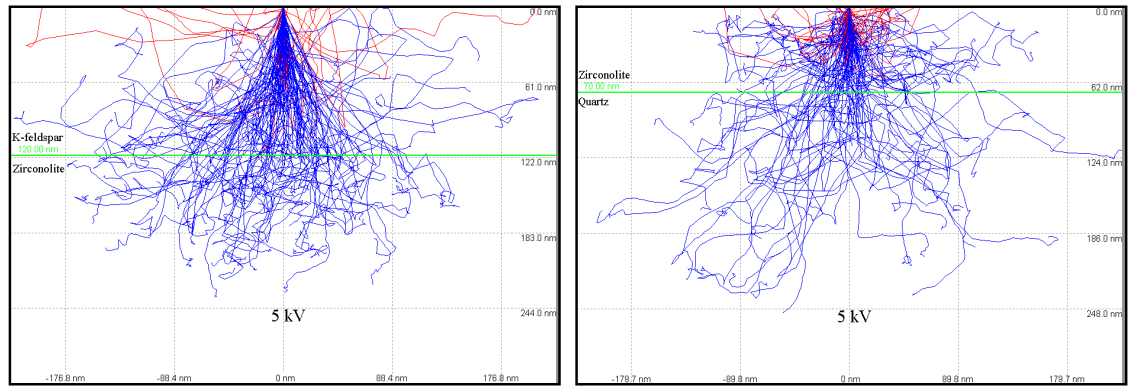

3. Model with $120 \mathrm{~nm}$ of K-feldspar overlying zirconolite (left) and70 nm of zirconolite overlying quartz. Red lines give the paths of BSEs.

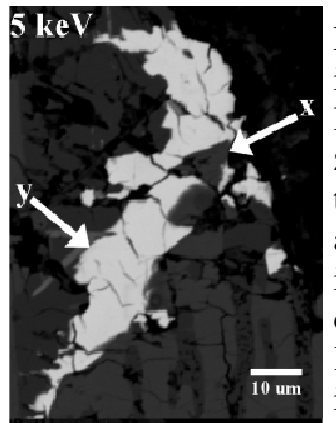

FIG. 2. BSE

images of the largest zirconolite grain taken at 5, 15, and $25 \mathrm{kV}$. "x" is a region overlain by thin K-feldspar. "y" is a region of thin zirconolite. Thin layers become transparent in images taken at higher voltage since the backscattered electrons penetrate deeper into the sample.
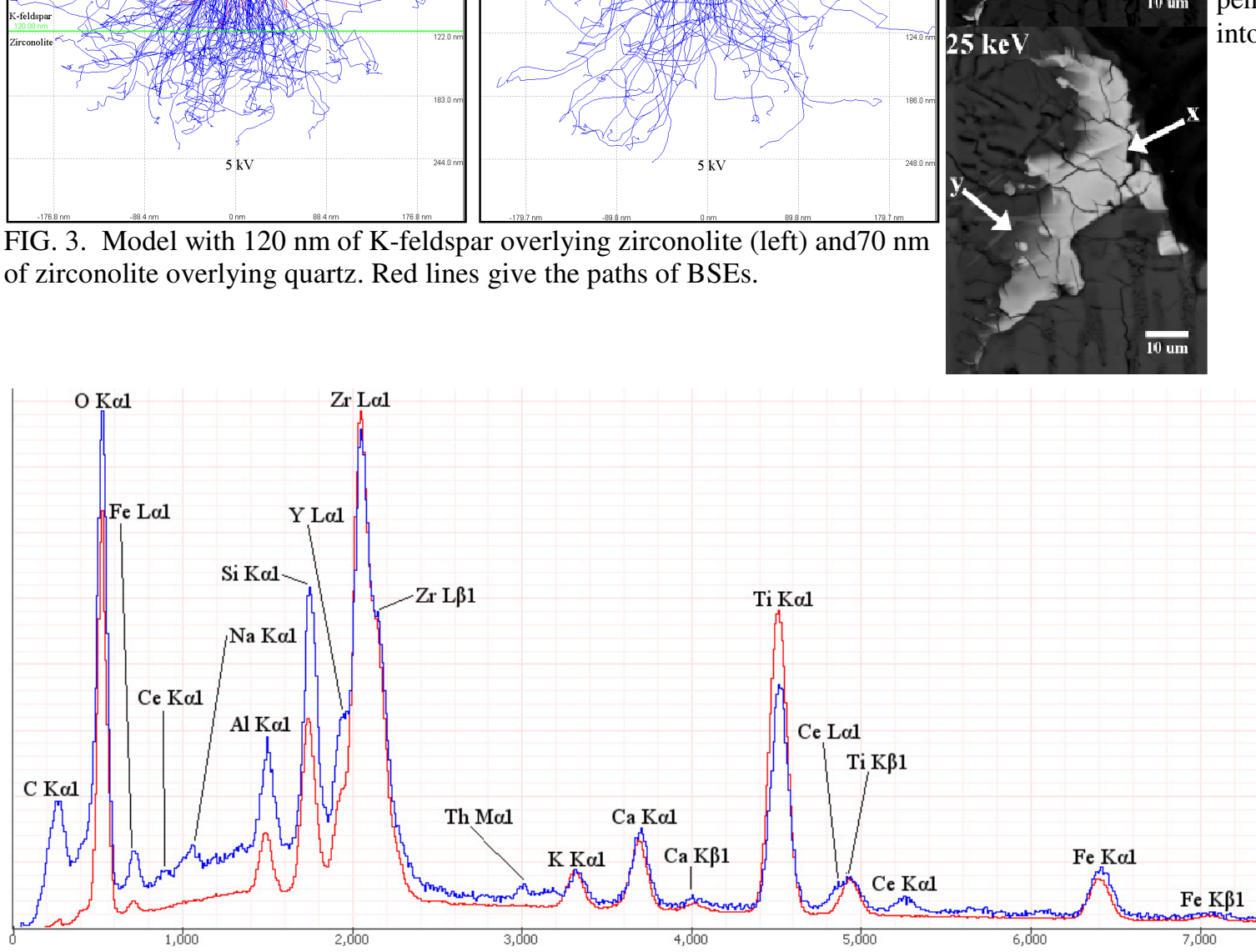

FIG. 4. Measured (blue) and modeled [6] (red) EDS spectra of $120 \mathrm{~nm}$ of K-feldspar overlying zirconolite at $15 \mathrm{kV}$.

Carbon line is from the sample's carbon coat. * is a peak resulting from a $\mathrm{Zr}$ and two $\mathrm{O} \mathrm{X}$-rays arriving at the detector concurrently. 